\title{
An Agenda without a Plan: Robert E Lucas's Trajectory through the Public Debate
}

\author{
Aurélien Goutsmedt \\ Université Paris 1 Panthéon Sorbonne-CES \\ Duke University - Center for the History of Political Economy \\ Aurelien.Goutsmedt@univ-paris1.fr
}

Danielle Guizzo

University of the West of England (Bristol, UK)

danielle.guizzoarchela@uwe.ac.uk

Francesco Sergi

University of Bristol

francesco.sergi@bristol.ac.uk

\begin{abstract}
This article explores Robert E. Lucas's policy agenda and his engagement with the public debate between 1968 and 1987. It investigates how he interacted with the public debate by envisioning key principles of his macroeconomic theory and methodology, and how he promoted his policy agenda. An exploration of Lucas's personal and professional archives sheds light on his participation in policy debates after the publication of his works, illustrating how Lucas built a discreet and cautious way of engaging with the public. Lucas did not envision an action plan, nor proposed a detailed program to implement his policy agenda. The article suggests that Lucas's originality compared to his contemporaries was his belief on the ability of macroeconomics to scientifically devise binding policy rules that could be integrated in an economic constitution.
\end{abstract}

Keywords: Robert E. Lucas; Lucas Critique; Monetary policy; Fiscal policy; Tax policy; Policy rules 


\section{Introduction}

In 1988, Alan Blinder accused the New Classical economics of representing the "triumph of conservative ideology over liberalism" (Blinder, 1988, 278). Like many at the time, Blinder associated Robert E. Lucas's work with "right-wing ideology" and "laissez-faire" (ibid., 286), relating the success of New Classical economics to the conservative turn in the United States at the end of the 1970s. Our article explores Robert E. Lucas's political vision and his interventions in the public sphere, shedding light on his links with the political debate of the late 1970s and early 1980s. ${ }^{1}$ Even though Lucas built his reputation from his theoretical and methodological contributions to macroeconomics, this article reveals less-known aspects of his writings. He developed a specific view of the functioning of market economies, besides offering some considerations on economic expertise and core policy recommendations that followed his methodological and theoretical framework.

Our work bridges a gap between two separate types of literature. On the one hand, the history of economic thought focuses on Lucas theory and methodology, depicting him as the intellectual leader of a fundamental change in macroeconomics (Hoover, 1988; Vercelli, 1991; Backhouse and Boianovsky, 2013; De Vroey, 2016). On the other hand, the literature discussing the role of free-market advocates such as Milton Friedman (Cherrier, 2011; Burgin, 2012), Friedrich Hayek (Caldwell, 2008; Burgin, 2012) or James Buchanan (MacLean, 2017) in the public debate grants a minor role to Lucas. Despite his links with each of these approaches and with the Economics Department of the University of Chicago, Lucas's thought and participation in the public debate has been ignored by both kinds of literature. Thus, this article draws a broader portrait of Lucas as an economist in the public debate.

Instead of focusing on Lucas's theories, the article pursues an investigation of his trajectory through the "lens of practice" (Stapleford, 2017), i.e. exploring how he was "doing economics" (ibid.), through an analysis of his discourse, his policy recommendations and the use of economic concepts in various contexts. Therefore, our original sources include both academic and non-academic published writings, as well as unpublished materials from Lucas's archives - constituting an essential source to unveil on Lucas's engagement with the public debate. $^{2}$

First, we show that during the 1970s and early 1980s, Lucas developed a well-defined vision of macroeconomic policy issues, addressing policy recommendations for the U.S. economy.

\footnotetext{
1 Our goal is not to argue that Lucas's macroeconomic work was influenced by ideology and political considerations, but rather to show that it was not limited to theoretical and methodological considerations.

${ }^{2}$ Archives are essential because, given the discretion of Lucas's engagement with the public debate, it would otherwise be impossible to detect it from other sources. However, an important caveat to be raised about the use of archive research of a living scholar is the possibility of a sample bias. Put differently, the sample of documents can be subject to an intended selection process in order to create a specific character, or aspirational self. This problem is inherent to the use of any archive and, more broadly, to a historical reconstruction relying on the sole writings of the author. Conscious of this, our work also uses other sources (academic papers, press, and congressional records) to build a consistent investigation of Lucas's thought and action.
} 
We will refer to these recommendations as his "policy agenda". We illustrate how Lucas's agenda consistently relied on his own peculiar set of political beliefs, as well as on his theoretical and methodological stances. This led him to criticize both the "Keynesian" regime of expertise and Arthur Laffer and the "supply-siders". We then connect and contrast Lucas's views with the ones addressed by Friedman, Hayek, and Buchanan, highlighting the originalities of Lucas's thought.

Secondly, we show that Lucas was not actively promoting his policy agenda: he did not propose any "action plan" to implement successfully his policy recommendations. ${ }^{3}$ In comparison to other major macroeconomists of the 1970s, such as Karl Brunner, Friedman, Lawrence R. Klein, Franco Modigliani or Robert Solow, his interventions on policy issues remained scarce. He was not a predominant figure in the press nor in the political public debate; similarly, he was not actively contributing to policy-making institutions, government bodies, lobbies or think tanks. Nevertheless, thanks to archival evidence, we shed light on his discreet and cautious way of engaging with the public debate: Lucas followed closely the policy and political debates of the time (especially antagonizing Ronald Reagan's policies), corresponded with politicians, delivered few interventions in the press, and animated the debate with his peers who were working in policy-making institutions.

\section{Lucas's Policy Agenda}

Lucas developed and expressed a well-defined vision of macroeconomic policy issues, as well as policy recommendations for the U.S. economy, in several articles (1977, 1978, 1979, 1980a) and in particular in "Rules, Discretion and the Role of Economic Advisor" (1980b). Lucas rejected what he called "meticulous day-to-day management" of economic policy (i.e. devising immediate and temporary action for current problems) advocated by Keynesianism as well as by "supply-side" economics that inspired the Reagan administration. ${ }^{4}$ Instead, Lucas urged for a long-term vision relying on "institutional design" of binding rules for economic policy. This agenda relied on his belief in market stability, as well as on rational expectations.

\footnotetext{
${ }^{3}$ Our work discusses Lucas's interactions within the public sphere, not his influence. In other words, we focus on Lucas's writings and practices, and not on the influence on (or reception by) others of his contributions. For instance, Lucas's (1976 [1973]) famous Critique lived "a life of its own and means different things to different people", as emphasized by Lucas (2012) himself: the reception of this idea is then beyond the scope of our paper (for an account of the reception of the Lucas Critique, see for instance Goutsmedt et al., 2019). We also do not refer to the interaction of the public with the broader stream of ideas coming from Lucas's closest co-authors (Thomas Sargent, Neil Wallace, Edward Prescott).

${ }^{4}$ Note that, in the 1980s, the label "supply-side economics" could refer to different groups. It could refer to the study of the effects of tax policies on supply - to contrast with the Keynesian focus on demand - as in Feldstein (1978) and Boskin (1978). Lucas (1990) refers to this latter when using this label—and claiming his role as a forerunner of this approach (Lucas and Rapping, 1969). Outside academia, the label came to designate the idea (popularized by Laffer and his curve) that decreasing taxes will increase government revenue. Today, though Feldstein and Boskin both advised Reagan's administration (Campagna, 1994), the label is mostly associated with Laffer. In our article the label refers to this second, contemporary meaning.
} 


\subsection{Fighting the Keynesians and Supply-siders' Policy Agendas}

Lucas suggested that macroeconomists had been historically addressing two types of policy agendas, which he called "day-to-day management" and "institutional design". For him, early business cycle theorists of the beginning of the $20^{\text {th }}$ century (such as Hayek and Wesley Mitchell) conceived macroeconomics as devoted to "institutional design": that is, "[identifying] institutional sources of instability" in order to mitigate economic fluctuations by "appropriate institutional changes" (Lucas, 1977, 8). For Lucas, this view was overshadowed by the General Theory and its subsequent developments, which brought a "sharp change in the nature of the contribution to policy which economists hoped to offer and which the public has come largely to accept." (ibid.) This change stemmed from the "belief that policy could affect immediate, or very short-term, movements of the economy from an undesirable current state, however arrived at, to a better state" (ibid., Lucas's emphasis). Instead of aiming at mitigating fluctuations, this new policy agenda focused on the concept of "involuntary" unemployment. This implied that economic policy "can and should be directed at the attainment of a particular, specifiable level of the measured rate of unemployment" (Lucas, 1978, 353).

The debate between these two policy agendas had, for Lucas, deeper roots in a divergent set of political beliefs: they resulted from another long-standing and "never changing" conflict between "mercantilism and government intervention vs. laissez faire and free market" (Lucas in Levy, 1993, 3). In a draft to his review of Tobin's Asset Accumulation and Economic Activity (1980), Lucas argued that "two schools of macroeconomic (and perhaps all) social policies" existed, and proposed different policy agendas. Those aiming at "[keeping] the power of government to injure" (sic) would be inclined to endorse institutional design; those aiming at "exercise [power] more effectively" would adopt a day-to-day management (RLP, Box 23, Folder "Tobin"). As Lucas further asserted, the inner division between the two policy agendas followed the belief (or the lack of faith) in the self-regulating ability of market economies. Therefore, choosing between institutional design and day-to-day management equated to decide whether "the role of government in stabilization policy should be to reduce its own disruptive part or actively to offset private sector instability" (Lucas, 1981a, 235).

According to Lucas, the rise of Keynesian macroeconomics and its day-to-day management policy agenda intertwined with an overall shift in U.S. political beliefs towards more government intervention. Keynesian macroeconomics rather "rationalizes this activism" (Lucas, 1980b, 267), which was established by the Employment Act of 1946:

\footnotetext{
${ }^{5}$ The Employment Act—an “American version" of Britain's 1944 White Paper (Employment Policy White Paper. London: Ministry of Reconstruction, 1944, Cmd: 6527)—resulted from the efforts of Alvin Hansen (a Federal Reserve Board consultant at the time), other Harvard economists (Richard Gilbert, Walter Salant, Gerhard Colm) and U.S. decision-makers from the Federal Reserve Board and Budget Bureau to call for a formal governmental commitment to full employment. It emphasized economic stabilization, which included attacking both deflation (one of Hansen's concerns) and inflation, as well as stimulating aggregate demand not only via government spending, but also through changes in tax structure to spur private investments. Given
} 
[Keynesian macroeconomics] defined itself to be that body of expertise the existence of which was presupposed in the Employment Act, and its practitioners devoted themselves to the development and refinement of forecasting and policy evaluation methods which promised to be of use in the annual diagnosis-prescription exercise called for by the act. (Lucas, 1980b, 201)

For Lucas, the Employment Act also fostered a change in the role of the macroeconomist in the public sphere and his relationship with policymakers. Academic knowledge would then be devised to support economic expertise, "equipping" experts with tools for "operational guidance" on a daily basis:

Within the existing institutional framework, the role of the economic expert as day-to-day manager expanded rapidly, and the role of the academic macroeconomist became that of equipping these experts with ideas, principles, formulas which gave, or appeared to give, operational guidance on the tasks with which these economic managers happened to be faced. (ibid. 202)

The postwar expansion seemed to justify the day-to-day management policy agenda supported by Keynesian macroeconomics and fostered by the Employment Act - though "it is impossible to distinguish good luck from good policy" (Lucas, 1977, 10). But it faced a crisis with the 1970s stagflation, which for Lucas resulted from policy mistakes in the 1960s (Goutsmedt, 2017). Therefore, during the early 1980s, Lucas relentlessly blamed the persistence of this specific policy agenda despite its apparent failure. U.S. institutions, academics, policymakers, and the general audience still demanded immediate action on current economic problems. For Lucas, the mass media played a major role in devising "new" problems and in urging "new" theories for policy-making:

To the journalist, each year brings unprecedented new phenomena, calling for unprecedented new theories (where "theory" amounts to a description of the new phenomena together with the assertion that they are new). (Lucas, 1980a, 697)

According to Lucas, the 1973 oil shock aftermath fueled the development of new ad hoc models for day-to-day management: ${ }^{6}$

This is the legacy of stagflation: a general loss of confidence, whether scientifically warranted or not, in the formerly accepted framework guiding discretionary economic management. Since the demand for discretionary policies remains strong, we are seeing the proliferation of new "solutions" to "short-run" policy problems, defended by the promise of

Hansen's specific understanding of Keynesianism, there is some controversy on the role of the Employment Act as a benchmark to Keynesian macroeconomic policy in the postwar (Guizzo, 2016).

${ }^{6}$ Here, Lucas targeted specifically Laffer and Arthur Okun (see Lucas, 1980b, 204). 
particular results but without basis in either theory or historical experience." (Lucas, 1980b, 204)

In Lucas's view, the same attitude remained widespread among macroeconomists, both in policy-making institutions and in academia. As an illustration, he targeted Paul McCracken et al.'s (1977) OECD report "Towards Full Employment and Price Stability". ${ }^{7}$ Lucas (1979, 162) attacked such kind of "vacuous" patchwork of "ambiguous and unsupported opinions" that exemplified the crisis of day-to-day management. The report proposed a "list of issues which have been defined in popular debate as "policy problems" and associated to these problems a "treatment by government action" without any "consistent set of economic principles underlying either the choice of questions to be addressed or the policy stances which are recommended" (ibid.). Lucas thought most academics shared the same unfortunate attitude. At the National Bureau of Economic Research (NBER) Bald Peak conference (October 1978), Stanley Fischer asked Lucas, William Poole, and Solow to prepare a discussion of "what policy should have been in 1973-75" (Fischer, 1980, 2-3). In his speech, Lucas objected:

Economists who pose this "What is to be done, today?" question as though it were somehow the acid test of economic competence are culture-bound (or institution-bound) to an extent they are probably not aware of. They are accepting as given the entirely unproved hypothesis that the fine-tuning exercise called for by the Employment Act is a desirable and feasible one. (Lucas, 1980b, 208)

When commenting on Tobin (1980), Lucas explicitly raised the question of alternative policy agendas:

Does [Tobin] think that our economic authorities should continue to formulate monetary and fiscal policy on a year-to-year basis, as unconstrained as they now are by legislative or constitutional limits on what policies may be selected, or does he see our task as that of designing new rules of the game, and conceiving institutional frameworks capable of enforcing them? (Lucas, 1981d, 564)

Lucas considers that having followed this day-to-day policy agenda for years had proven to be eventually catastrophic during the 1970s, and the time had come to promote a change:

The capitalist democracies have paid dearly for their neglect of this question over the past decade. If we continue to evade it, as I read Tobin advocating we do, we are in for a good deal worse. (ibid., 566).

\footnotetext{
${ }^{7}$ McCracken has also been chairman of the Council of Economic Advisers (1969-1971) under Nixon.
} 
The "culture-bound" or "institutional-bound" made the day-to-day management agenda so persistent and widespread that both Keynesian and non-Keynesian macroeconomists were perpetuating this way of thinking. In an opinion column in The New York Times Magazine, Lucas also argued that supply-side economics and Keynesian economics represented two sides of the same coin:

Today, deficit spending is rationalized by the novel doctrines of supply-side economics. Yesterday, the same policies were defended by the logic of Keynesian economics (Lucas, $1981 c)^{8}$

Lucas believed that changing this state of affairs required a transformation of macroeconomics that would result in a change in the conduct of economic expertise. ${ }^{9}$ The rise of Keynesian ideas promoted and rationalized a specific policy agenda for macroeconomics, based on day-to-day management; similarly, the transformation in macroeconomic theory and methodology Lucas was devising would have led to another policy agenda.

\subsection{Lucas's Policy Agenda: Macroeconomics as Institutional Design}

Lucas's policy agenda changed the scope of macroeconomic policies from involuntary unemployment to the business cycle. Without any "coherent idea as to what full employment means or how it can be measured" (Lucas, 1978, 353), it made no sense to devise monetary and fiscal policies to tackle this imaginary involuntary unemployment---this is even "real and dangerous hypocrisy", and it "does no service to unemployed people to talk about it as though it were" (Lucas, 1987, 105). ${ }^{10}$ Lucas's arguments mirrored one of Friedman's (1968, 10) arguments that targeting unemployment was purposeless since there is no way of measuring a full-employment or a natural rate of unemployment.

The level of unemployment (that is, the "equilibrium" or "natural" level of unemployment) was still a relevant policy issue to Lucas; however, he considered it to be an issue for public

\footnotetext{
${ }^{8}$ Lucas was scathing not only against Laffer's "ad hoc" theory (see above), but also against other supply-siders. One of the targets of Lucas's criticism was Jude Wanniski, a Wall Street Journal columnist, influential advocate of supply-side economics, and author of The Way the World Work (1978). Contacted by the Olin Foundation, George Stigler asked Lucas for his opinion about the book. Lucas considered that Wanniski's book does not worth "occupying the time of any contemporary critics" (RLP1, Folder 1980 3/3).

${ }^{9} \mathrm{He}$ recognized that promoting such a change was difficult, at least as long as "the economic manager responsible for advising ... the size of the coming fiscal year deficit [will be] uninterested" in listening to it (Lucas, 1980b, 201). However, he saw an "encouraging" signal in the adoption of Resolution 133-integrated in the Federal Reserve Act in 1977 (ibid., 208). The resolution committed the Fed to maintain long run growth of monetary supply consistent with the economy's long run potential growth (Weintraub, 1978).

10 This idea echoed Lucas's theoretical and methodological project for macroeconomics (see De Vroey, 2016, chapters 9-11). One of the distinctive assumptions introduced by Lucas (in Lucas and Rapping, 1969) is that unemployment always results from workers' choices. Workers decide to supply hours of labor according to the optimal (utility-maximizing) intertemporal allocation of their time between leisure and consumption; as wages and prices are always instantaneously converging to their equilibrium levels, no involuntary unemployment is possible.
} 
finance and welfare economics, whereas macroeconomics should be concerned solely with the business cycle. Then, Lucas saw two separate approaches in policy-making - each one dealing with one specific policy issue:

The policy problem of reducing business cycle risk is a very real and important one, and one which I believe monetary and fiscal policies directed at price stability would go a long way toward achieving. The problem of finding arrangements for allocating unemployment risks over individuals ... is also important, and can be analyzed by the methods of modern welfare economics. (Lucas, 1981a, 246)

Welfare economics can deal with unemployment "in total ignorance of the nature of business-cycle dynamics", while "the discovery of better business cycle theories will contribute little or nothing" to the understanding of welfare issues such as social insurance or income distribution (Lucas, 1987, 105). ${ }^{11}$ Further, macroeconomics cannot provide any relevant policy insight about reducing the unemployment level. For instance, since market economies are assumed to converge instantaneously towards the equilibrium level of unemployment, aggregate demand policies cannot affect durably the level of unemployment. Lucas emphasized that macroeconomic policy should focus exclusively on mitigating business cycles; or, put differently, to reduce the variance of macroeconomic aggregates, primarily of the price level. This agenda, similarly to the day-to-day management approach, had deeper roots in the "never-changing" dilemma between the "two schools of macroeconomic policy" that differed on interventionism. As previously mentioned, whether "the role of government in stabilization policy should be to reduce its own disruptive part, or actively to offset private sector instability" (Lucas, 1981a, 235). Lucas never hid his preference for the first school and his faith in the self-regulating abilities of market economies.

Then, the role of macroeconomists is to "design institutions" ensuring a stable environment for economic activity. By "institutions" Lucas meant binding policy rules for the government to follow ("institutional arrangements which bind us to follow them", Lucas, 1981b, 564). In "Principles of Fiscal and Monetary Policy" (1986), Lucas clarified:

The most useful way to think about government policy is as a choice of rules of the game to which government is committed for some length of time" (104).

\footnotetext{
${ }^{11}$ For instance, welfare theory will discuss the level of unemployment compensation, which determines the natural rate of unemployment. "Severe penalties" for unemployed could for instance "reduce unemployment rates to any desired level", and also output (Lucas, 1981a, 246); whereas a generous compensation scheme would "involve a subsidy to being unemployed" (ibid.), but, by ensuring a sure current income, it could encourage risk-averse workers to seek a new job.
} 
This form of commitment is already valid for other, non-economic domains of public action: ensuring commitment to rules is simply the reason "why democratic governments have constitutions that are difficult to change and legal systems that respect precedents and 'due process" (ibid.). The same should be true for macroeconomic policies, and such rules need to encompass all governmental institutions involved. ${ }^{12}$

Then, Lucas endorsed Buchanan and Wagner's (1977) idea of enforcing an "economic constitution":

We need, in Buchanan and Wagner's useful terminology, an "economic constitution" and we are at last beginning to develop the economic theory that will be helpful in designing it. (Lucas, 1987, 104) $)^{13}$

In Lucas's view, two reasons justified the superiority of a policy agenda based on institutional design over that based on day-to-day management: optimality and scientificity. Lucas (1986) used optimality (or also, in his words, "efficiency", or: "for each citizen, attaining the highest welfare level", 129) as the criterion to decide among alternative economic policies. ${ }^{14}$ There, he presented a simple general equilibrium model to deduce "the neoclassical welfare-economic principles that bear on the efficient conduct of national, or aggregative, monetary and fiscal policy" (ibid., 117). The model emphasized how only policy rules can be optimal in terms of welfare. A crucial principle in supporting this argument was the notion of time-consistency (forcefully argued by Kydland and Prescott, 1977). As for designing institutions of macroeconomic policy, a general equilibrium model is essential to the extent it allows to "quantify the welfare cost of simple (and non-optimal) rules for fiscal and monetary management" (Lucas, 1986, 132).

In a nutshell, Lucas anchored his policy agenda about rules and institutional design in his theoretical and methodological view of macroeconomics: it presupposed that the macroeconomist should formulate a model with a theoretical framework consistent with what he identified as "general equilibrium" (meaning the Arrow-Debreu neo-Walrasian approach). This encompassed a set of distinctive assumptions: individual optimizing behavior, market clearing, and rational expectations. A macroeconomic model microfounded on this basis would, therefore, enable to deduce welfare functions to assess which rule would be optimal. However, for Lucas theoretical general equilibrium models that deal with optimality were not enough to justify a policy agenda scientifically. As emphasized by De Vroey (2011), Lucas

\footnotetext{
${ }^{12}$ As emphasized by Lucas's criticism of Reagan's tax policy (see infra, 3.3), the monetary and fiscal authorities should both commit to mutually consistent rules: "it is not within the abilities of any central bank to make things work out right in a society that insists that the real resources spent by its government can exceed, on a sustained basis, the resources that government extracts from the private sector via taxes.” (Lucas, 1981a, 30)

${ }^{13}$ See also Lucas $(1980 b, 209 ; 1986,132)$.

${ }^{14}$ Although the discussion of optimality of policy rules could be found already in Lucas (1972b, section 7), where he discussed Paretian optimality of a Friedman-type monetary policy rule over other monetary policy rules.
} 
was concerned with the inevitable intertwining of theory and political beliefs. ${ }^{15}$ Therefore, he considered that policy prescriptions drawn from theories can be translated into policy agendas if and only if they relied on an empirical basis. ${ }^{16}$ Macroeconometric models devoted to this task: providing scientific (empirical) assessment for alternative policies.

Lucas's emphasis on models did not display originality, given the well-established macroeconometric tradition of the 1970s and 1980s. He indeed recognized that advances in model-building were the most positive contributions to economics made by the Keynesian day-to-day management era (Lucas, 1980a, 701). Nevertheless, in his famous Critique (Lucas, 1976 [1973]), he rejected the possibility that such models would be able to provide any reliable quantitative evaluation of discretionary policy. He aimed precisely at demonstrating that

the ability to forecast the consequences of "arbitrary", unannounced sequences of policy decisions ... appears to be beyond the capability not only of the current-generation models, but of conceivable future models as well. (Lucas, 1976 [1973], 280).

The Lucas Critique argued that only rules can be assessed with "scientific quantitative policy evaluations" (ibid. 279, Lucas's emphasis), i.e. by using macroeconometric models. For Lucas, policy evaluation with macroeconometric models should rely on a description of the way economic agents would react to alternative policies. The analytical tools available made only possible to model such reactions for rules, but not for discretionary policies. The theoretical argument about optimality then became secondary:

The preference for "rules vs. authority" in economic policy making suggested by [my] point of view is not ... based on any demonstrable optimality properties of rules-in-general ... The point is rather that the possibility [that discretion can lead to superior economic performance] cannot in principle be substantiated empirically. (ibid., 279, Lucas's emphasis)

Lucas also recognized that, in practice, the development of such model-based quantitative assessment of policy rules remained unsatisfying (Lucas and Sargent, 1978, 62-63). Despite not being able then to determine scientifically what the optimal policy rule should be, Lucas

\footnotetext{
${ }^{15}$ According to De Vroey, Lucas claimed that, in practice, "ideology" (a set of political beliefs about how society works or should work) could hardly be separated from science. Macroeconomists (like any citizen) hold ideological views, and then most theoretical propositions in macroeconomics are intertwined with ideology. Thus, policy conclusions derived from theory are not ideology-free; on the contrary, they are also embedded with the implicit ideology in the premises of a theory. For instance, Lucas $(1977,25)$ argued that assuming market clearing logically implies that countercyclical policies will be of limited use; therefore, one can conclude that the market clearing assumption is ideologically biased.

${ }^{16}$ Put differently, ideology cannot be separated from macroeconomic theory, but it can be "neutralized" with empiricism - it is only by neutralizing the ideological bias that theories can provide scientific policy prescriptions.
} 
still considered that there was enough support for, on the one hand, an immediate abandoning of day-to-day management, and, on the other hand, implementation of some "good approximation" of the optimal rule. Lucas considered Friedman's four percent rule of money growth as a "good approximation" of an optimal rule for monetary policy. Even if it "would have welfare consequences differing trivially from the optimum policy", "[it] would be easy to spell out and monitor" (Lucas, 1986, 132-133).

When addressing the specifics of the policy rules that an "economic constitution" should enforce, Lucas did not really differ from Friedman. In The New York Times Magazine (Mermelstein, 1979, 32) and in his academic article for the NBER Bald Peak conference (1980b), Lucas supported Friedman's “A Monetary and Fiscal Framework for Economic Stability” (1948) and A Program for Monetary Stability (1959). Lucas's policy prescriptions corresponded to the following rules: 1) a $4 \%$ annual rate of growth of M1;2) a cyclical federal government spending and tax rates 3) a balanced federal budget; 4) no government intervention to fix wages and prices. ${ }^{17}$ These four measures would "fully protect the economy against sustained inflation" and "entirely eliminate erratic monetary and fiscal shocks as independent sources of instability" (Lucas, 1980b, 207), in order to provide "a stable, predictable environment for the private sector of the economy" (ibid. 210). ${ }^{18}$

Lucas's defense of rules and their constitutionalization establishes common ground between him and the main advocates of free markets and government limitation in the 1970s in the U.S. First, with Hayek's Law, Legislation and Liberty (1978), which proposed to integrate into the constitution the prohibition of progressive income taxation. Second, with Buchanan: as we saw, Lucas praised several times Buchanan and Wagner's idea in Democracy in Deficit of an economic constitution aiming at, among other things, limiting fiscal deficits (see Lucas, 1980b, 209; 1986, 132; 1987, 104). ${ }^{19}$ Third, and more importantly, Lucas agreed with Friedman's views on economic policy, especially those he formulated with Rose Friedman in Free to Choose. There, constitutionalization of economic policy was described as "the equivalent of the First Amendment to limit government power in the economic and social area - an economic Bill of Rights to complement and reinforce the original Bill of Rights" (Friedman and Friedman, 1980, 299). ${ }^{20}$ An important part of this new "Bill of Rights" should

\footnotetext{
${ }^{17}$ This last point is rather inspired by Lucas's own opposition to Nixon wage-price control ( $c f$. infra).

${ }^{18}$ Another kind of binding rules seemed appealing to Lucas. He appeared enthusiastic about the tax revolts of 1978 in California that led to an amendment to the Constitution of the State, the Proposition 13, which established a limitation to property taxation (Lucas, 1980b, 204).

${ }^{19}$ Esteem was mutual. In a letter dated from August 7th 1980, Buchanan confessed that he liked Lucas's "Death of Keynesianism" (1980c), a strong piece against Keynesian economics presented in 1979 in Chicago's Graduate School, and that he agreed "with almost all of what [Lucas] sa[id]". Buchanan claimed that he was optimistic for the years to come as it "must be the time for more widespread discussion of constitutional reforms, not only in monetary matters, but generally" (RLP1, Folder 1980 1/2).

${ }^{20}$ In a letter from January 22nd 1980, Lucas thanked Friedman for having sent him a copy of Free to Choose and explained that he jumped to the Chapter 10 as he was particularly interested by the issue of the constitutional approach to monetary growth (RLP1, Folder 1980 1/2).
} 
be a rule that "require[s] the monetary authorities to keep the percentage rate of growth of the monetary base within a fixed range." 21 (ibid. 308)

However, despite this proximity on the issue of economic rules and constitutionalization, Lucas's thought on economic policy and its elaboration carried some originality. Notably, his firm belief in the ability of mathematical models to estimate empirically the optimality of policy rules anchored him in a form of scientific positivism, which certainly distinguished him from Hayek and Austrian economics (Hoover, 1988, Chapter 10). His commitment to the neo-Walrasian general equilibrium model contrasted with Friedman's preference for Marshallian partial equilibrium model (Hoover, 1984; De Vroey, 2011).

These differences are neither minor nor anecdotal. Lucas's methodology for macroeconomics went hand in hand with his considerations on economic policy and the role of economists in it. To a large extent, his policy agenda relied on macroeconometric modellingmacroeconomists must find optimal rules - while being in the same time independent of itmodels were not yet ready to perform this task, but it did not prevent Lucas for defending rules.

The connection between Lucas's political beliefs and his methodological and theoretical considerations appears in a conference he gave in New York in March 1977. ${ }^{22}$ Lucas explained in the introduction that he regarded as peculiar to be asked to talk about "New Ideas on economic policy" since what he defended- "stable monetary growth and balanced government budget" - was not new and was close to the thought of "Coolidge or McKinley" (RLP39, Folder Mitchell, Hutchins Conference). ${ }^{23} \mathrm{He}$ added that his reasons "for favoring such "passive" policies" were not "more sophisticated than ideas current in Coolidge's day", that is to say "a belief that if government and the Fed can keep their own affairs in order, proceeding smoothly and predictably, the private sector will take reasonably good care of itself" (ibid.). However, he then proceeded to convince people that do not have yet this belief-like him "ten years ago"- based on his theoretical analysis of Keynesian policy agenda and the impact of rational expectations for economic policy.

However, despite a clear policy agenda, neither Lucas committed himself fervently to defend economic rules and their constitutionalization, nor did he engage in any modelling work for public or private policy institutions. Whenever he carries some involvement in the public sphere, it seems to have been always unintended and in the margin.

\footnotetext{
${ }^{21}$ These strong similarities on the issue of rules and constitutionalization shall not make forget the potential differences that exist between NCE and Friedman, stemming from the use of rational expectations. It has some importance for instance on the path to choose for disinflation policies, as what is primordial with rational expectations is the credibility of the policy rather than the money stock variations. But these differences with Friedman and monetarism by advocates of rational expectations are much visible in Sargent's work than in Lucas's (see Goutsmedt 2018).

${ }^{22}$ Lucas was invited to present on "New Ideas on economic policy" by Mitchell, Hutchins Inc., a Wall-Streetbased financial firm selling securities research services..

${ }^{23}$ William McKinley was the 25th President of the U.S. from 1897 to 1901, and Calvin Coolidge the 30th from 1923 to 1929.
} 


\section{Lucas's Trajectory through Public Debate (1969-1987)}

Lucas's intervention in the public domain appeared more discreet than those of other prominent macroeconomists of the time, such as Brunner, Friedman, Klein or Solow. It nevertheless reveals his view of current events; more importantly, Lucas's interventions consistently echoed his policy agenda. Lucas's activity took place in the U.S. context of the 1970s and early 1980s, which saw radical changes in economic policy (Nixon's wage-price controls, the Humphrey-Hawkins Act, Volcker's disinflation, the tax revolts, and Reagan's tax cut plan). We claim that Lucas got involved in these debates, but without actively engaging to promote his policy agenda and impose his views. On the contrary, most of Lucas's interactions with the general audience seemed unintended or passive: Lucas was solicited by others to express or clarify his views about policy issues. This resulted in an engagement with the public that was cautious and discreet-and outside policy-making institutions.

\subsection{Searching for New Theoretical Perspectives: Lucas at Carnegie, 1966-1969}

During his first years as an associate professor at the Graduate School of Industrial Administration at Carnegie Institute of Technology (Carnegie hereafter), Lucas worked, with his colleagues, on an empirical research agenda (Lucas, 1967a; 1967b; McGuire et al, 1968). However, by the end of the 1960s, Lucas progressively shifted his research focus. The blooming of new ideas at Carnegie fostered the development of his distinctive approach to macroeconomics, based on rational expectations and general equilibrium. The influence of senior faculty members (e.g. John Muth and Herbert Simon) is widely acknowledged, both by Lucas himself (Lucas, 1996) and by recent historical works (Darity et al., 2004). Co-writing with young scholars at Carnegie, as Edward Prescott, also influenced Lucas's new approach to macroeconomics (da Silva, 2017).

During these years, Lucas's participation in the public debate or in policy-making expertise remained quite limited, except from 1966 to 1967, when he worked as an external consultant for the Bureau of Budget to assess the impact of changes in taxation on firms' investment (RLP39, Folder Bureau of Budget). In 1969, the US Department of Health, Education and Welfare offered him a position in their research department. Lucas, however, turned down the offer: "I'm afraid I am not willing to spend time away from my research during the next year or so" (RLP1, Folder 1969).

Nevertheless, Lucas considered that discussing political issues was part of economists' job. In 1968, Lucas wrote an open letter to Carnegie's President Guyford Stever to express his support for political discussions within the faculty. ${ }^{24}$ Lucas argued that it would be "difficult

\footnotetext{
${ }^{24}$ Following the circulation at Carnegie of different materials against the Vietnam War, President Stever had blamed, in a letter to the faculty (11/01/1968), the use of the university's resources ("mails, mimeograph service") to express "personal thinking on controversial public issues".
} 
and dangerous" to draw a clear line between "scholarly and political activity", and pledged in favor of policy-oriented academic research:

most research [in economics] is quite explicitly directed toward improving public economic policy. ... it would seem to me to be altogether appropriate to advocate these policies [produced by my research] via letters to newspapers, to congressmen, and so forth, in addition to describing my results in academic journal articles. I regard both types of activity as part of my professional life, equally entitled to the support of school services. (ibid., Folder 1968 1/1, Lucas to Stever, 01/02/1968)

However, Lucas did not seem to write any "letters to newspapers, to congressmen" during this period, although he supported his colleague Leonard Rapping in doing so. Rapping wrote to Congressman William S. Moorhead, a democratic representative for Pittsburgh district: "[I] and three of my colleagues [at Carnegie] (Professor Martin Geisel, Professor Robert Lucas and Professor Richard Roll) would be willing to serve as unpaid consultants" (RLP1, Rapping to Moorhead, 21/05/1969). Rapping supported Moorhead's motion to cut military spending (CR, Vol. 115, 25/04/1969) and his "attempt ... to take on the Military and its numerous supporters". Rapping suggested that his role would be to help the Congressman overcome his "substantial disadvantage vis-à-vis the Defense Department", given that the latter disposes of "incredible resources, both in terms of money and manpower" (ibid.).

Overall, the first period of Lucas's career seems to have been dominated by his academic work and the early development of his new approach to macroeconomics. However, Lucas did not overlook political and policy issues.

\subsection{The Years of "High Theory": Lucas at Carnegie, 1969-1973}

Between 1969 and 1973, Lucas published the path-breaking articles that became his most famous contributions to macroeconomics. His work during this period was driven by requests or funding originating from policy-making institutions or policy-oriented solicitations.

The period between June 1969 and the end of 1971 was crucial. Lucas spent the summer at the NBER (1970) and received a fellowship from the Brookings Institution (1970-1971; RLP1, Folder 1969, Folder 1970 1/2). In June 1969, the Federal Reserve Board invited Lucas to write a paper about the "econometric testing of the natural rate hypothesis", to be presented by November 1970 at a Fed conference about "The Econometrics of Price Determination" (ibid.). This commissioned paper became "Econometric Testing of the Natural Rate Hypothesis" (Lucas, 1972a), further published in the proceedings of the conference (Eckstein, 1972). In the same period, Lucas completed his "Expectations and the Neutrality of Money" (1972b).

Lucas also contributed to the new series of macroeconomics conferences, the "CarnegieRochester Series on Public Policy", organized by Karl Brunner and Allan Meltzer. For the first meeting, Lucas had agreed in December 1972 to write a "literature review on the studies 
on the Phillips curve" (RLP1, Folder 1972): this paper became "Econometric Policy Evaluation: A Critique" (1976 [1973]).

Earlier in 1972, Brunner wrote to Lucas a letter on a related matter (RLP1, Folder 1972, Brunner to Lucas, 14/01/1972). Brunner asked him to join a group with other 30 U.S. economists to cooperate in order to gain influence on the public debate about economic policies. ${ }^{25}$ Brunner argued how media coverage was biased ("one-sided reports") toward the "dominant vision" supporting "much and better regulation” (ibid.). According to Brunner:

It is time that economists with professional record and some reservation about the general propensity to find "solutions" in more controls, or larger budgets, assert themselves more effectively in public policy discussion. ${ }^{26}$ (ibid.)

With Brunner's office serving as a "clearing house", the group could easily "distribute the cost of attending repetitively and somewhat systematically to important issues" and provide "an established organization to prepare and launch statements" (ibid.). ${ }^{27}$ Lucas answered enthusiastically: "Yes, I would like very much to be a part of the group you describe ... I would like to help in any way I can" (ibid., Lucas to Brunner, 19/01/1972). However, such a network group was never implemented: instead, in 1973, Brunner initiated with Allan Meltzer (Carnegie) a smaller group focused on monetary issues, the "shadow open market committee" (SOMC), to which Lucas did not take part (Meltzer, 2000).

\subsection{The "New Guru” from Chicago (1973-1986)}

The publishing of "Econometric Policy Evaluation" (as a working paper, in Fall 1973) symbolizes a turn in Lucas's career and a new phase of his engagement with the public. In 1974, Lucas decided to move back to the University of Chicago after the Economics Department had sent him a full professorship offer. He spent the rest of his professional career, also serving as vice-chairman (1975-1983) and then chairman (1986-1988).

From the beginning of 1974, Lucas received many letters asking for a copy of the Critique. William Poole reported to Lucas: "my copy of [your paper] is wearing out from people reading it, unstapling it, Xeroxing it, and restapling it" (RLP1, Poole to Lucas, 01/11/1975). Lucas's paper disseminated to a larger and larger audience after its publication in the Carnegie-Rochester Series on Public Policy (1976). Media coverage on Lucas (and, more broadly, on "rational expectations" macroeconomists) gained momentum: between 1975 and 1981, articles about Lucas appeared in Newsweek, The Wall Street Journal, Fortune, Business

\footnotetext{
${ }^{25}$ Brunner presented the idea as "originating from discussion with several friends last summer in Europe", an almost certain reference to a meeting of the Mont Pèlerin Society.

${ }^{26}$ A reference to Nixon's wage-price controls policy (August 1971).

${ }^{27}$ Brunner did not limit the group functions to "launching statements" but also envisaged assuring that "at least one of our group is invited to important Congressional Hearings" or bringing "our case to a wider attention by means of Press Conferences or television interviews" (ibid.).
} 
Week, The New York Times Magazine, and, in Europe, The Economist and Der Spiegel. ${ }^{28}$ Probably in response to this coverage, the University of Chicago (through its Office of Public Information) released a press résumé about Lucas, emphasizing the policy implication of his work:

[the theory of rational expectations adds] some potent fuel to the argument long associated with Milton Friedman that government attempts to regulate economic activity are not beneficial. [...] government economic policies are a waste of time and effort. ${ }^{29}$ (RLP1, Folder $19772 / 2$ )

The same year, Republican representative John Rousselot used the Lucas Critique as a backbone argument for criticizing the federal budget before the Congress:

Mr. Speaker, the following [statement] provides a concise and effective critique on the reliability and worth of econometric models. In that, the figures we are debating today and tomorrow are based on the calculations and results of these Keynesian models. I think it is helpful to understand the faulty assumptions on which they are based. (CR, vol. 130, 22/02/1977)

The statement introduced by Rousselot was actually written by Paul Craig Roberts, a Republican economic advisor. ${ }^{30}$ The statement belonged to a broader strategy for defending the Kemp-Roth bill (which aimed at a massive cut on households' income tax): jointly with the use of the Lucas critique to criticize the CBO model, Roberts also presented alternative results using another econometric model. Afterwards, Roberts corresponded with Lucas, soliciting his advice on the matter:

I have seen your critique of econometric policy evaluation. The subject has now been officially raised in the U.S. Congress [by Rousselot], and I believe your comments on the enclosed exchange [CR mimeo] might be a positive contribution to public economic policy. (RLP1, Roberts to Lucas, 21/03/1977)

\footnotetext{
${ }^{28}$ For instance, Business Week's (8/11/1976, 74-75) headline was: "How Expectations Defeated Economic Policy". The article presented Lucas and Sargent as "ivory-towered economists" providing "solid theoretical base" to Friedman's policy assertions and going "even beyond": "no systematic policy can be devised that is affecting anything other than the inflation rate". Der Spiegel (29/11/1976) gave a similar interpretation: "for Lucas, the best stabilization policy ... is to do nothing".

${ }^{29}$ However, the text clarifies below that Lucas "disagree[s] with Friedman" on altering the money supply to stabilize the economy (ibid.).

${ }^{30}$ Professor at George Mason (alongside with his former PhD supervisor Buchanan; MacLean, 2017, 181-82) Roberts also contributed from the beginning to the redaction of the Kemp-Roth bill. Roberts was hired by Representative Jack Kemp in 1974, and he built (with Norman B. Ture) an econometric model to support the bill and to undermine CBO's results (Blyth, 2002, 163). Roberts later played a key role in Reagan's campaign and administration (Crouse, 2018, 217).
} 
The discussion initiated by Rousselot went on during the session of the Joint Economic Committee of the Congress (CR, vol. 130, 24/06/1977). The Wall Street Journal (18/04/1977, 29/06/1977) covered both debates, further amplifying the echo of Lucas's idea in the public debate.

The media success of the Lucas Critique made it particularly appealing to people outside academia, including researchers in private corporations (Monsanto, Merrill Lynch) and policy-making institutions. Dozens of letters to Lucas asked for a copy or send him enthusiastic appreciation (RLP1, Folder 1978 1/4 to Folder 1978 4/4). ${ }^{31}$ By the end of the 1970s, Lucas enjoyed then a well-established reputation and fame going beyond the academic circles, a reputation that will stand during the 1980s. For instance, when invited to give a conference at Ohio State University in 1983, the organizer wrote to Lucas: "[attending your lecture], in addition to faculty and graduate students, there will be numerous undergraduates and curious people from the business community who wants the views of the "new guru" from Chicago" (RLP13, Folder "Lectures Notes 1979-1980", William Dewald to Lucas). ${ }^{32}$ During this period, Lucas also wrote two academic articles $(1977$; 1980a) that clarified and systematized his views. Additionally, he edited two books of collected writings, one on his own (1981a) and another co-edited with Sargent (1981). Perhaps the most representative piece of this period is another article with Sargent, "After Keynesian Economics". Presented at a conference organized by the Federal Reserve Bank of Boston in 1978, the paper was a "frankly rhetorical piece" as the authors themselves described it (RLP, Box 19, Folder "After Keynesian Macroeconomics 1978-1979”, Lucas to Sargent, 09/02/1978). ${ }^{33}$

Besides this academic-oriented effort to disseminate his work, Lucas engaged with the public to clarify his views, which shows that Lucas's academic production aligned with his increasing engagement with the public. He continued to correspond with politicians, such as, for instance, Congressman Phillip Crane. ${ }^{34}$ In these letters, Lucas clarified to Crane some of his views on economic policy that the Congressman held from a recent article published by Newsweek:

\footnotetext{
${ }^{31}$ The public also consulted Lucas about other topics. For instance, Stephen Neal (a Democratic representative) consulted Lucas about the idea of publishing minutes from the Federal Open Market Committee. Lucas praised this suggestion, which will enhance transparency and predictability (RLP1, Folder 1976 2/2).

${ }^{32}$ Also, this reputation travelled outside the U.S. Lucas received also a significant number of letters from German and Japanese economists, and Models of Business Cycles (1987) was immediately published in a Japanese edition (RLP13, Folder "Models of Business Cycles").

${ }^{33}$ On this episode, see Goutsmedt (2017). Lucas also drew from this piece to give a talk at the Graduate School of Chicago's Annual Management Conference in 1979, called "The Death of Keynesian Economics" (see DeVroey, 2016, 210).

${ }^{34}$ Crane was a prominent GOP representative and chairman (1977-1979) of a powerful conservative lobby, the American Conservative Union. He later ran for the nomination for president in 1980, against Reagan.
} 
My work has not focused on particular policy issues ... Much of it has been devoted to explaining why our econometric models cannot be used to "fine tune" the economy. (RLP1, Folder 1978 4/4)

During this new phase of his interaction with the public, Lucas seemed more inclined to speak in the media about policy issues. ${ }^{35} \mathrm{He}$ also publicly criticized Reagan's administration. In two columns published in The New York Times (26/08/1981, 28/08/1981), Lucas discusses the lack of long-term consistency of the Economic Recovery Tax Act, arguing that it was "discouraging", as it would lead to higher deficits. ${ }^{36}$ To make his case, Lucas drew a rhetorically strong parallel between his stance and Alexander Hamilton's "Reports on the Public Credit" (1790-1795), presented before Congress as Secretary of the Treasury. By paying a tribute to Hamilton and his foresighted management of the public debt, Lucas attacked Reagan's administration for following the opposite path. For Lucas, Hamilton's central argument "was the recognition that a policy-decision taken today is, like it or not, an announcement of general principle by which analogous situations are to be treated in the future." (1981b) Conversely, Reagan's administration implemented inconsistent decisions to attain an equilibrated budget: on the one hand, tax-cuts; on the other, a monetary policy promising price stability. Combined, these decisions lacked credibility, as their objectives were "obviously inconsistent" (ibid.). Rational expectations constituted the theoretical underpinning of Lucas's opposition to Reagan's policy: if public deficit soared, households and firms would fear debt financing by money creation, what would counter the monetary policy implemented by Paul Volcker since October 1979. More generally, through his participation to the public debate, Lucas seemed to hold the laymen in higher esteem than policymakers. Most of his policy agenda relied on the "virtues" of the common people, namely their capacities to pursue their own interest in a consistent and forward-looking way - in other words, their economic rationality. This underpinned Lucas's faith in the selfregulating abilities of market economies and the negative view of government discretionary intervention.

Lucas's columns did not go unnoticed and led GOP Senator Ernest Hollings to ask his advice about a plan for reducing deficits he had just proposed before Congress. Lucas agreed with

\footnotetext{
${ }^{35}$ Lucas was for instance interviewed on BBC2 program "The British Economy" (RLP, Box 5, Folder 1982 2/2). However, Lucas felt sometimes that media coverage was not faithful to his ideas. In a letter to a journalist of The New York Times Magazine (RLP13, Folder "Directions of macroeconomics", Lucas to Mermelstein, undated 1979), Lucas complained harshly about his views being "paraphrased by journalists with different background and objectives than mine". We can also add to the list of Lucas's interviews his conversation with Klamer (1984), even though it was intended for an academic audience.

${ }^{36}$ The act was the fulfillment of the Kemp-Roth project. Lucas had been opposed since the beginning to this project: he received the evaluation of the results of the tax cuts, which relied on econometric simulation of the Chase Econometric Forecasting Model---the model was managed by Michael K. Evans, who was convinced of the relevance of Laffer and supply-siders' ideas (Blyth, 2002, 163). Lucas rejected the simulations, regarding them as "just pulled out of the air" (RLP1, Folder 1979 2/4). He considered that they should contact Martin Feldstein or Robert Barro, if they wanted "competent quantitative evidence on fiscal policy".
} 
Hollings" "emphasis on fiscal discipline" and that "the Reagan-Kemp-Roth tax cut was a mistake" (RLP1, Folder 1981 1/2). Lucas's policy agenda pushed him to fight against the supply-siders-inspired policies. That is why Lucas appeared reluctant to be assimilated to a certain vision of U.S. conservatism associated with Reagan's administration, which he publicly criticized:

It's hard to be a conservative with the Reagan administration turning to fine-tuning, which seems insane to me. So, if being conservative means liking their economics, I guess I'm not. (Lucas in Klamer, 1984, 51)

\section{Concluding Remarks}

This article has drawn a broader portrait of Lucas, emphasizing the connections between his worldview, his methodology for macroeconomics and his policy recommendations. These aspects of Lucas's work relied on his belief in rational agents, self-stabilizing markets and the likely harmfulness of government interventions. Lucas's policy agenda, as it appears in his writings, exhibited many similarities with some recommendations made by free-market advocates of that time. Nevertheless, Lucas's originality lied in the importance given to macroeconomics: he believed in the scientific elaboration of binding rules, which would be part of an economic constitution, as well as in the necessary methodological transformations for the discipline, aiming at building new models able to assess "scientifically" optimal rules. The weight he granted to macroeconomics when dealing with policy issues could have explained his discretion in the public sphere, and why his acknowledgments were mostly academic. Indeed, it is possible that Lucas's form of engagement with the public debate could have resulted from personal reasons. Following his own justification, this could relate to individual characteristics: "I don't think I personally have any particular talent or liking for [advice-giving]" (Lucas in Snowdon and Vane, 291). For Lucas, the most important issue was to push for the development of new practices in macroeconomics that would encourage and facilitate the kind of policies he envisioned. Adopting a discreet and cautious way to deal with public debate would have the advantage of strengthening his scientific legitimacy and protecting him (to a certain extent) from being accused of ideological commitments.

Such a strategy complied with what Lucas called a "division of labour" (ibid.) among his colleagues. ${ }^{37}$ For instance, Sargent completed Lucas's work by developing a more concrete "Rational Expectations Theory" of inflation, thus proposing a New Classical explanation of U.S. stagflation (Goutsmedt, 2018). However, the subsequent spread of New Classical ideas outside academia and their influence in policy-making institutions remains largely to be recounted. In this story yet to build, the Federal Reserve Bank of Minneapolis could

${ }^{37}$ And then he adds: "I am glad that other people do [take] the role of advice-giving" (ibid.) 
constitute an important step in a larger channel between academic and policy: not only Sargent and Prescott were employed by the Bank as researchers, but also its president (Mark Willes) publicly defended the relevance of rational expectations to understand inflation and monetary policy. In this sense, the use of the Lucas Critique in the Congress and the adoption of rational expectations by the supply-siders behind Reagan (Blyth, 2002, Greider, 1982) could have played a significant role.

Therefore, Lucas's interaction with the public sphere differed from the other economists discussed in this special issue: Lucas was not an official (or informal) advisor to politicians or policymakers, counselling and eventually changing their mind about concrete policies (such as Walter Heller, or Albert Hirschman); he was not intervening in the public debate through the medias, popularization books or conferences to persuade or educate the laymen (as did Arthur Pigou); he was not a member of any consultative body to policy-making institutions, producing technical advice and guidance to the conduct of economic policy (such as Modigliani or Klein). Nevertheless, his own way to intervene in the public debate raised questions about the different channels by which economics and economists could influence public reason.

\section{References}

\section{Archives}

CR

Congressional Records, U.S. Government Publishing Office, Washington (DC). Available online at https://archive.org/

RLP

Robert E. Lucas Papers, 1960-2011 and undated. David M. Rubenstein Rare Book \& Manuscript Library, Duke University, Durham (NC).

RLP1 RLP, Boxes 1 to 4. Correspondence, 1968-1981.

RLP13 RLP, Box 13. Drafts and lectures notes, 1979-1980.

RLP39 RLP, Box 39. Professional services series.

\section{Published References}

Backhouse, Roger and Mauro Boianovsky. 2013. Transforming Modern Macroeconomics. Exploring Disequilibrium Microfoundations (1956-2003). Cambridge: Cambridge University Press. 
Blinder, Alan. S. 1988. The Fall and Rise of Keynesian Economics. Economic Record, 64(4): 278-294.

Blyth, Mark. 2002. Great transformations: Economic ideas and institutional change in the twentieth century. Cambridge: Cambridge University Press.

Boskin Michael J. 1978, Taxation, Saving, and the Rate of Interest, Journal of Political Economy, 86(2): 3-S27.

Burgin, Angus. 2012. The Great Persuasion: Reinventing Free Markets since the Depression. Harvard: Harvard University Press.

Brunner, Karl and Alan H. Meltzer. 1976. Introduction to the Series. Carnegie-Rochester Conference Series on Public Policy, 1(1): ii, suppl. to the Journal of Monetary Economics.

Buchanan, James M. and Richard E. Wagner. 1977. Democracy in Deficit. The Political Legacy of Lord Keynes. New York: Academic Press.

Caldwell, Bruce. 2008. Hayek's challenge: An intellectual biography of FA Hayek. Chicago: University of Chicago Press.

Campagna, Anthony S. 1994. The Economy in the Reagan Years: The Economic Consequences of the Reagan Administration. London: Greenwood Publishing.

Cherrier, Béatrice 2011. The lucky consistency of Milton Friedman's science and politics, 1933-1963. In Robert Van Horn, Philip Mirowski and Thomas A. Stapleford (Ed.) Building Chicago Economics: New Perspectives on the History of America's Most Powerful Economics Program, Cambridge (UK): Cambridge University Press. 335-67.

Crouse, Eric R. 2018. America's Failing Economy and the Rise of Ronald Reagan. Berlin: Springer.

Darity, Warren, Robert Leeson, and Warren Young. 2004. Economics, Economists and Expectations: From Microfoundations to Macroapplications. London: Routledge.

da Silva, Danilo F. R. 2017. Lucas's Research in the Late 1960s and the Natural Rate of Unemployment. History of Political Economy, 49(1): 137-159.

De Vroey, Michel. 2011. Lucas on the Relationship Between Theory and Ideology. Economics: The Open-Access, Open-Assessment E-Journal, 5(2011-4): 1-39.

De Vroey, Michel, 2016. A History of Modern Macroeconomics from Keynes to Lucas and Beyond. Cambridge: Cambridge University Press. 
Eckstein, Otto. 1972. The Econometrics of Price Determination. Washington (DC): Board of Governors of the Federal Reserve System, Publications Services, Division of Administrative Services.

Feldstein, Martin S. 1978, The Welfare Cost of Capital Income Taxation, Journal of Political Economy, 86(2): 29-51.

Fischer, Stanley, (ed.). 1980. Rational Expectations and Economic Policy. Chicago: University of Chicago Press.Friedman, Milton. 1948. A Monetary and Fiscal Framework for Economic Stability. American Economic Review, 38(3): 245-264.

Friedman, Milton. 1948. A Monetary and Fiscal Framework for Economic Stability. American Economic Review. 38(3): 245-264.

Friedman, Milton. 1958. A Program for Monetary Stability. New York: Fordham University Press.

Friedman, Milton. 1968. The Role of Monetary Policy. The American Economic Review, 58(1): 1-17.

Friedman, Milton, and Rose D. Friedman. 1980. Free to Choose: A Personal Statement. New York and London: Harcourt Brace Jovanovich.

Goutsmedt Aurélien. 2017. Stagflation and the Crossroad in Macroeconomics: The Struggle between Structural and New Classical Macroeconometrics. Paris: Documents de travail du Centre d'Économie de la Sorbonne, 2017.43.

Goutsmedt Aurélien 2018. Thomas Sargent face à Robert Lucas : une autre ambition pour la Nouvelle Economie Classique. OEconomia, 8(2): 211-244.

Goutsmedt, Aurélien, Erich Pinzón-Fuchs, Matthieu Renault, and Francesco Sergi. 2019. Reacting to the Lucas Critique: The Keynesians' Pragmatic Replies. History of Political Economy, In press.

Greider, William. 1982. The Education of Daniel Stockman and Other Americans. New York: EP Dutton.

Guizzo, D. 2016. Keynes, Keynesian Economics and the Political Economy of Power of the Postwar World. PhD Dissertation, Curitiba (PR), Federal University of Paraná.

Hayek, F. A. (1978). Law, Legislation and Liberty. Vol. 1. Chicago: University of Chicago Press Economics Books. 
Hoover, Kevin D. 1984. Two Types of Monetarism. Journal of Economic Literature, 22(1), 58-76.

Hoover, Kevin D. 1988. The New Classical Macroeconomics. A Skeptical Inquiry. Oxford: Basil Blackwell.

Klamer, Arjo. 1984. The New Classical Macroeconomics. Conversations with the New Classical Economists and Opponents. Brighton: Wheatsheaf Books.

Kydland, Finn E. and Edward C. Prescott. 1977. Rules Rather than Discretion: The Inconsistency of Optimal Plans. Journal of Political Economy, 85(3): 473-491.

Levy, David. 1993. Interview with Robert E. Lucas Jr. The Region, June 1993.

Lucas, Robert E. 1964. Substitution Between Labor and Capital in U.S. Manufacturing, 19291958. Doctoral dissertation, University of Chicago. Reedited as: Robert E. Lucas. 1969. Capital-Labor Substitution in U.S. Manufacturing. In Arnold C. Harberger and Martin J. Bailey (eds) The Taxation of Income from Capital, Washington (DC): The Brookings Institution.

Lucas, Robert E. 1967. Tests of a Capital-Theoretic Model of Technological Change. The Review of Economic Studies, 34(2): 175-189.

Lucas, Robert E. 1972a. Econometric Testing of the Natural Rate Hypothesis. In Robert E. Lucas (ed.), Studies in Business-Cycle Theory, Cambridge, Mass.: MIT Press, 90-103.

Lucas, Robert E. 1972b. Expectations and the Neutrality of Money. Journal of Economic Theory, 4(2): 103-124.

Lucas, Robert E. 1973b. Some International Evidence on Output-Inflation Tradeoffs. American Economic Review, 63(3): 326-334.

Lucas, Robert E., 1976 [1973]. Econometric Policy Evaluation: A Critique. CarnegieRochester Conference Series on Public Policy, 1: 19-46. First published in Carnegie-Mellon Working Paper Series, May 1973.

Lucas, Robert E., 1977. Understanding Business Cycles. Carnegie-Rochester Conference Series on Public Policy, 5: 7-29.

Lucas, Robert E. 1978. Unemployment Policy. American Economic Review, 68(2): 353-357.

Lucas, Robert E. 1979. A Review of Paul McCracken et alii "Towards Full Employment and Price Stability: A Report to the OECD By a Group of Independent Experts”. In Karl Brunner, 
K. and Allan H. Meltzer, Policies for Employment, Prices and Exchange Rates, CarnegieRochester Series on Public Policy, Amsterdam: North-Holland.

Lucas, Robert E. 1980a. Methods and Problems in Business Cycle Theory. Journal of Money, Credit and Banking, 12(4):696-715.

Lucas, Robert E. 1980b. Rules, Discretion, and the Role of the Economic Advisor. In Fischer, Stanley (ed.), Rational Expectations and Economic Policy, Chicago: University of Chicago Press, 199-210.

Lucas, Robert E. 1980c. The Death of Keynesian economics. Issues and Ideas, 2.

Lucas, Robert E. 1981a. Studies in Business Cycle Theory. Cambridge, Mass.: MIT Press.

Lucas, Robert E. 1981b. Inconsistency in Fiscal Aims. The New York Times, Friday, August $28^{\text {th }}, 1981$.

Lucas, Robert E. 1981c. Economic Scene: Deficit Finance and Inflation. The New York Times, Wesneday, August $26^{\text {th }}, 1981$.

Lucas, Robert E. 1981d. Tobin and Monetarism: A Review Article. Journal of Economic Literature, 19(2): 558-567.

Lucas, Robert E. 1986. Principles of Fiscal and Monetary Policy. Journal of Monetary Economics, 17(1986): 117-134.

Lucas, Robert E. 1987. Models of Business Cycles. Oxford: Basil Blackwell.

Lucas, Robert E. 1990. Supply-side Economics: An Analytical Review. Oxford Economic Papers, 42(2): 293-316.

Lucas 1996. Robert E. Lucas Jr. Biographical. In Tore Frängsmyr (ed.), The Nobel Prizes, Stockholm: Nobel Foundation, available at

https://www.nobelprize.org/nobel_prizes/economic-sciences/laureates/1995/lucas-bio.html (retrieved 17/04/2017).

Lucas, Robert E. 2001. Professional Memories. Nobel Economists Lecture Series at Trinity University, San Antonio, Texas.

Lucas, Robert E. 2004. Keynote Address to the 2003 HOPE Conference: My Keynesian Education. History of Political Economy, 36(5):12-24. 
Lucas, Robert E. 2012. Q\&A: Robert Lucas on Modern Macroeconomics. Economic Dynamics Newsletter, 14 (1): 1-2.

Lucas, Robert E. and Leonard A. Rapping. 1969. Real Wages, Employment, and Inflation. Journal of Political Economy, 77(5): 721-754.

Lucas, Robert E. and Edward C. Prescott. 1971. Investment Under Uncertainty. Econometrica, 39(5): 659-681.

Lucas, Robert E. and Thomas J. Sargent. 1978. After Keynesian Macroeconomics. In After the Phillips Curve: Persistence of High Inflation and High Unemployment, Boston, Mass: Federal Reserve Bank of Boston, 49-72.

Lucas, Robert E. and Thomas J. Sargent. 1981. Rational Expectations and Econometric Practice. London: George Allen and Unwin Ltd.

MacLean, Nancy. 2017. Democracy in Chains: The Deep History of the Radical Right's Stealth Plan for America. New York: Penguin Books.

McCracken, Paul W. et al. 1977. Towards Full Employment and Price Stability: A Report to the OECD by a Group of Independent Experts. Paris: OECD.

McGuire, Timothy W., John U. Farley, Robert E. Lucas, and Winston L. Ring. 1968. Estimation and Inference for Linear Models in Which Subsets of the Dependent Variable Are Constrained. Journal of the American Statistical Association, 63(324): 1201-1213.

Meltzer, Alan H. 2000. The Shadow Open Market Committee: Origins and Operations. Journal of Financial Services Research, 18(2-3), 119-128.

Mermelstein, David. 1979. The Threatening Economy. The New York Times, Sunday, December $30^{\text {th }}, 1979$.

Snowdon, Brian and Howard R. Vane. 2005. Modern Macroeconomics: Its Origins, Development and Current State. Cheltenham: Edward Elgar.

Stapleford, Thomas. 2017. Historical Epistemology and the History of Economics: Views Through the Lens of Practice. Research in the History of Economic Thought and Methodology, 35A: 113-145.

Tobin, James. 1980. Asset Accumulation and Economic Activity. Reflections on Contemporary Macroeconomic Theory. Oxford: Basil Blackwell. 
Vercelli, Alessandro. 1991. Methodological Foundations of Macroeconomics: Keynes and Lucas. Cambridge: Cambridge University Press.

Wanniski, Jude, 1978. The Way the World Works: How Economies Fail-and Succeed. New York: Basic Books.

Weintraub, Robert E. 1978. Congressional Supervision of Monetary Policy. Journal of Monetary Economics, 4(2), 341-362. 